Workplace culture in psychiatric nursing described by nurses

(Short title: Workplace culture in psychiatric nursing)

K. KURJENLUOMA ${ }^{1}$ BHS, A. RANTANEN ${ }^{2} \mathrm{PhD}$, B.

MCCORMACK ${ }^{3}$ DPhil(Oxon), BSc(Hons), Nurs, PGCEA, RGN, RMN, FEANS, FRCN, Professor of Nursing Research, P. SLATER ${ }^{4}$ BSc, MSc, PhD, Lecturer in Statistics, N. HAHTELA ${ }^{5}$ PhD, T. SUOMINEN ${ }^{6}$ $\mathrm{PhD}$

${ }^{1,}{ }^{2}$ University Teacher, Adjunct Professor, ${ }^{5},{ }^{6}$ Professor, School of Health Sciences, University of Tampere, Finland, ${ }^{3}$ Professor and Head of the Division of Nursing, School of Health Sciences, Queen Margaret University, Edinburgh, Scotland, ${ }^{4}$ Ulster University, Northern Ireland

Correspondence:

K. Kurjenluoma

School of Health Sciences

University of Tampere

33014 Tampere

Finland

Telephone number: +358407025518

E-mail: kaisa.kurjenluoma@gmail.com 


\section{Acknowledgments}

We would like to thank all of the nurses who participated in our research, and the two hospital districts which kindly gave us the approval to conduct this study.

\section{Author contribution}

Study design: K.K., A.R., T.S.

Data collection and analysis: K.K.

Drafting of manuscript: K.K., A.R., T.S.

Critical revisions for important intellectual content: A.R., B.MC., P.S., N.H., T.S.

Supervision: T.S.

Statistical expertise: A.R.

\section{Funding}

This study has been partly funded by the Competitive State Research Financing of the Expert Grant Responsibility Area of Tampere University Hospital (Grant 9S065).

\section{Ethical approval}

Based on Medical Research Act (488/1999) in Finland no statement from Ethical Committee was needed. No ethical issues were identified and study was conducted under the guidance provided by the Declaration of Helsinki (2013). 


\title{
Workplace culture in psychiatric nursing described by nurses
}

\begin{abstract}
Aim: This study looks to describe the workplace culture from the viewpoints of stress, job satisfaction and practice environment. Methods: Data were collected from nurses $(n=109)$ using a web-based survey, The Person Centred Nursing Index, from two purposefully selected hospital districts in Finland. Data were statistically analyzed. Results: Nurses described their workplace culture in slightly positive terms. Nurses only occasionally experienced stress (mean 2.56, SD 0.55), and were fairly satisfied with their job (mean 4.75, SD 0.66) and their practice environment (mean 4.42, SD 0.81). Demographic variables such as the nurses' age, length of time in nursing, time at their present hospital, working shifts, and their use of patient restriction were more frequently associated with their perceived workplace culture.
\end{abstract}

Conclusion: Older nurses and those with a longer work history in the nursing profession tended to be more satisfied with their workplace culture in psychiatric nursing. Young and/or newly graduated nurses felt more negatively on their workplace culture; this issue should be recognized and addressed with appropriate support and mentoring. Nurses who used restrictive measures were more often less satisfied with their workplace culture. Continuous efforts are needed to reduce the use of coercive measures, which challenge also the managers to support nursing practice to be more person-centred.

Keywords job satisfaction, job stress, psychiatric nursing, practice environment, workplace culture 


\section{Introduction}

During recent years there has been a global shortage of nurses $(1,2)$. Nurses are thinking of changing their profession, and the most common reasons given are that work is too stressful, there are few possibilities for career development, and that their workplace culture is not perceived as supporting their work $(3,4)$. In Finland, $25 \%$ of nurses under 30 years of age are reported as considering a change of profession (4). Therefore, workplace culture is an important issue when the shortage of nurses is seen as influencing the day-to-day life of nurses (5).

In recent decades, the provision of psychiatric services has changed dramatically in both hospitals and outpatient services through a process of deinstitutionalization. During the 1990s, psychiatric and somatic health care systems became integrated in Finland (6). This trend can also be seen on an international level, with decreasing lengths of stay in the hospital setting and increasing psychiatric patient numbers being seen in community care (7). These changes have had an effect on the workplace culture in psychiatric hospitals. The work demands more flexibility from nursing staff, e.g. in how they have used to work while the lengths of patients' stay decreases and the new requirements for the care in shorter period need to be fulfilled. (8). There is some research about workplace culture in psychiatric nursing, for example from the point of view of resistance to change (9), coercive measures $(10,11)$, and the use of restraint (12). However, to our knowledge there is a dearth of research concerning the workplace culture from the psychiatric nursing point of view. This study looks to describe the workplace culture from the viewpoint of stress, job satisfaction and working environment. 


\section{Background}

Workplace culture reflects the values that persons share in their workplace, including the norms, assumptions, social order and beliefs that the workplace holds $(13,14,15)$. Sullivan and Decker (16: 27) describe workplace culture as the unstated "rules of the game". It is essential to have some common values and beliefs that could be shared, as the staff work together towards achieving goals in their workplace. Workplace culture has an influence on employee performance (13). As such, leaders, managers and employees, need information that can be used to evaluate the current situation in the workplaces, and to establish what kind of changes are needed to be made in order to develop the workplace culture, and also to evaluate the outcomes of these changes (5).

The elements of workplace culture e.g. job stress, job satisfaction and the practice environment affect nurses' motivations to work in the nursing profession and their likelihood to stay at a particular place of work (17). Stress entails: "an individual's perception of a stimulus as overwhelming, which in turn elicits a measurable response resulting in a transformed state" (18: 71). In psychiatric nursing, sources of stress are seen as workload, relationships with other people, and conflicts in the workplace $(19,20)$. Job satisfaction is defined as how favourable nurses see their job (3). The job satisfaction of psychiatric nurses is affected by issues such as being collegial to others, patient-related work, changes at work, and autonomy (21). The practice environment means the physical environment where nurses work, but also reflects issues such as autonomy, leadership and the relationships with other professionals in the work place (22). A clean, functioning practice environment has been seen to raise psychiatric nurses' enthusiasm for their work and also to raise the quality of care that they provider (21 Psychiatric nurses have identified teamwork, control over practice, leadership and autonomy as areas that influence their practice environment (8). In this research, job stress, job satisfaction and the practice environment are seen as the dimensions of workplace culture. 
In Finland, municipalities are responsible for the provision of social and health care services for people who experience mental illnesses or disorders. Most of the municipalities purchase psychiatric hospital services from hospital districts because psychiatric hospital care is defined as specialized medical care according to Finland's Act on Specialized Medical Care (1062/1989), The Mental Health Act (1116/1990) and The Health Care Act (1326/2010) $(23,24,25)$.

\begin{abstract}
Aim of the study
This study looks to describe the workplace culture from the viewpoint of stress, job satisfaction and practice environment. More specifically our research questions were: How do psychiatric hospital nurses' describe their workplace culture, and which variables are associated with it?
\end{abstract}

\title{
Methods
}

Design and setting

The cross-sectional data were collected in two purposefully selected hospital districts in Finland from September 2014 - January 2015. Questionnaires distributed to all of the nurses $(\mathrm{N}=577)$ who worked in adult psychiatric hospital settings in the selected districts, and included head nurses, registered nurses, mental health nurses and licensed nurses.

Instrument

Data were collected using a structured standardised questionnaire. The first part of the questionnaire covered demographic details (e.g. their age, sex, and marital status), and their workplace (e.g. occupation, working length in mental health nursing, frequency of deprivation of patient's liberty) (table 1 and 2). The second part of the questionnaire comprised of the Person Centred Nursing 
Index (PCNI) by Slater and McCormack (2007), which has been reported to be valid and reliable (e.g. 26, 27). The permission to use the instrument was received from the copyright holders. Previously the instrument measures of homogeneity has been good, with a Cronbach's alpha range of $0.57-0.92$ (2009). In this study, the Cronbach's alpha range was from $0.58-0.95$, with all but one construct achieving satisfactory scores.

The PCNI measures three factors of workplace culture: nurses' stress, satisfaction and their practice environment, which are divided into 19 constructs (table 3). The instrument has 78 items that are evaluated with a seven-point $(1=$ never/no stress/very dissatisfied/strongly disagree to $7=$ always/extreme stress/very satisfied/strongly agree) Likert-scale. Due to some technical issues, one item was missing from the total sum of the working environment. One missing item could have affected the total sum of stress.

\section{Data collection}

Permission to conduct the study was obtained from the hospital districts administrations and no statement from Ethical Committee was needed based on Medical Research Act (488/1999) of Finland (28). All participants received an e-mail from a Chief Nursing Officer, which contained a link to the web-based questionnaire and information regarding research. The link was anonymous, in that neither the researcher nor the organization involved were able to identify the people or facilities that were used to answer the questionnaire.

\section{Sample}

A total of 109 nurses completed the questionnaire, which represents an $18.9 \%$ response rate.

\section{Data analysis}

Data were analysed using standard descriptive statistics. The individual 78 items of workplace culture were summed based on the instrument manual to 22 summary variables, which contained 
between 3 to 35 items (table 3 ). Three of the 22 summary variables are the factors of workplace culture (stress, satisfaction and practice environment), which together consist of 19 constructs of workplace culture. These variables were analysed in order to determine their normal distribution using histograms and the Kolmogorov-Smirnov test. Five sum variables were normally distributed and 17 were skewed. Non-parametric tests were used to address the issue of non-normality of distribution of data.

Of the background factors, reclassification was used for the variables of restrictions and coercive measures, based on how often nurses needed to deprive patients of liberty. New classes were constructed that we could explore relationships between workplace culture and restrictions and coercive measures. These responses were scored as: rarely $=1$, monthly $=2$, weekly $=3$ and daily $=$ 4. The new classes constructed in restrictions gave a total of points 3-6 meaning 'rare' and 7-12 points meaning 'often'. In relating to coercive measures, a total of 5-10 points means 'rare' and 1120 points means 'often'. The new class 'rare' is used to demonstrate that nurses are using restrictions and coercive measures more rarely than a weekly basis.

Differences for demographic variables among the characteristics of workplace culture were tested using parametric and non-parametric tests. We used t-test, one-way Anova, Kruskal-Wallis-test and Mann-Whitney U-test. However the group responses to the working time variable was too small to test for differences occurring within groups. The significance level was set at $p<0.05$ and the data were analyzed with statistical package for the social science 22.0 (SPSS) (29).

\section{Results}

\section{Background factors}

Nurses were aged from 22-69 years old (mean=42.1, SD 11.8). More than half of the nurses were female $(62.4 \%)$ and three quarters $(75.7 \%)$ worked as a registered nurse (table 1). Wards had an average of 16 beds $(\mathrm{SD}=2.4)$ and the average caseload was 15 patients $(\mathrm{SD}=2.79)$. At the time of 
the survey, wards had an average of 6 patients who were under observation or being treated against their own will $(\mathrm{SD}=5.28)$.

\section{Insert table 1 here.}

Most of the nurses worked in a ward equipped with a room for seclusion (78.9\%). Most of the time, these rooms are furnished with a mattress or with soft furniture. A bed for restraint can be available in the ward and can be moved to the room for seclusion purposes. A little over half of the nurses $(55.1 \%)$ had a restraint room in their wards. A restraint room is a room where a bed for restraint is ready for use. The most common way to enforce a deprivation of liberty was a restriction on leaving the ward (table 2). Over 65\% of nurses used such restrictions at least weekly. Around half (51.9\%) of the nurses secluded patients at least monthly, and about three quarters $(74.1 \%)$ of the nurses restrained patients on a less than monthly basis (rarely).

\section{Insert table 2 here.}

Workplace culture

Nurses described their workplace culture in slightly positive terms (table 3). Nurses only occasionally felt stress (mean $=2.56, \mathrm{SD}=0.55$ ), and the most stressful matter was workload (mean=3.49, $\mathrm{SD}=1.00)$. Nurses were fairly satisfied with their job (mean=4.75, $\mathrm{SD}=0.66$ ), and ranked personal (mean=5.16, $\mathrm{SD}=0.72)$ and professional (mean=5.01, $\mathrm{SD}=0.78)$ satisfaction most highly. Nurses felt slightly positive about their practice environment (mean=4.42, $\mathrm{SD}=0.81$ ). Issues regarding nurse management (mean $=4.88, \mathrm{SD}=0.84$ ) and an intention to leave (mean=4.88, $\mathrm{SD}=1.83$ ) received high values, meaning that nurse management was appreciated and that nurses did not want to leave their workplace.

Insert table 3 here. 
Some background variables were significantly associated with workplace culture (table 4, 5 and 6), although gender or job title were not seen to have any association. The length of time nurses had worked in their present hospital had significant associations with reported conflicts with other nurses, satisfaction with training, the overall practice environment, and perceptions of organizational commitment, nurse management and empowerment. Also, a nurse's age, working in shifts, their experience in nursing and the frequency they were called upon to use restraint/restriction had several significant associations with workplace culture. There were also significant associations between the use of restraint/restriction and overall satisfaction, especially professional satisfaction and nurses' satisfaction with pay and prospects. Further, the restriction frequency had a significant association with the practise environment and to nurses' intention to leave.

Insert tables 4, 5 and 6 here.

\section{Discussion}

Nurses described their workplace culture in slightly positive terms. A positive workplace culture has been indicated as something that might increase the quality of care (3).

The stress score was relatively low among nurses in this study, although similar results have previously been seen in psychiatric care (19). There may be some issues that could be associated to these kind of results. In psychiatric care the staff on the ward might have considerable contact with their colleagues, and derived help and a sense of value for their work from them. It may be more likely that they are not left alone to make difficult decisions and clear guidelines (for example guidelines on legal issues) help them. Nurses who work on psychiatric wards may usually be organized to work in teams or pairs than their colleagues in outpatient care and so receive support from others. 
In this research, nurses were satisfied with their work on both personal and professional levels. Previous research has shown that nurses who are satisfied with their work are more like to stay in their profession and remain working in their present hospital (3). However, previous research also shows that psychiatric nursing is an unpopular choice among young nurses (30), and this presents challenges to leadership, especially in the future when the shortage of nurses is likely to become worse. Managers need to recruit nurses and also retain them in the workplace, and as such, we have considered organizational characteristics as key factors.

Nurses felt more positively than negatively towards their practice environment. They were committed to the organization in that they wanted to work in their present hospital, and the findings were similar to those of a previous study where psychiatric nurses also held a slightly positive view of their practice environment (8). Nurses were also satisfied with their management. The duration of work in the nurses' present hospital had many significant associations with the practice environment. It seems that the longer nurses' stay at a certain hospital, the more positively they see their practice environment and are more committed to the organization.

In this research, restrictions were commonly used and had more significant associations with workplace culture than coercive measures. The Mental Health Act (1116/1990) in Finland and other regulations, mostly national and organizational give nurses and other health care professionals' clear guidelines on when to use seclusion, and perhaps such guidance helps to reduce stress and uncertainty at the workplace. However, some international guidance also exists (e.g. 31).

\section{Limitations}

There are some limitations to consider before drawing conclusions from the data in this study.

Firstly, the study design reflects a moment in time in this descriptive cross-sectional study. Secondly, the response rate was $18.9 \%$ which is relatively low. Possible reasons for the low response rate were that it was a web-based survey and that organizational changes were going on at 
the same time as the survey being conducted. Lastly, in the web-based survey, due to some technical issues, one item was missing from the total sum of the working environment. One missing item could have affected the total sum of stress. But the overall effect would be small because it is only one item missing from total of 36 items. However, the instrument used in this research has been previously found to be reliable and to offer a valid measurement for workplace culture. In these studies the instrument homogeneity has been good, with a Cronbach's alpha range of 0.570.92 (22). In this study, the Cronbach's alpha range was from 0.58-0.95 (table 3).

\section{Conclusions}

A positive workplace culture is associated with quality of care, and also with how long nurses are retained in their facilities and in nursing overall. Nurses who had worked longer in the nursing profession, and who are older tend to be more satisfied with their workplace culture. This poses challenges as to how young nurses may be attracted to work in psychiatric nursing, and also how they may be supported once in place. Young and/or newly graduated nurses need support and mentoring.

Psychiatric nursing has developed over recent decades. The issues of restrictions and coercive measures have gained more attention and efforts have been made to reduce the use of coercive measures, which from a perspective of workplace culture is important and needs to be continued. This is underlined in the findings of this study which showed that restrictions had significant associations with workplace culture, and that nurses who used restrictive measures were more often less satisfied with their workplace culture. 


\section{What the research adds to existing knowledge}

Nurses described their workplace culture in slightly positive ways. Demographic variables such as the nurses' age, length of time in nursing, time at their present hospital, working shifts, and their use of patient restriction were more frequently associated with their perceived workplace culture.

\section{Implications for mental health nursing}

Young and/or newly graduated nurses especially need support from managers to be committed to their work place. Young and/or newly graduated nurses have lower overall satisfaction and their commitment to the organization is lower. The use of restraint had significant associations with workplace culture, and those nurses who used restrictive methods more often, were less satisfied with their workplace culture in psychiatric nursing. These issues should be recognised in nursing practise, especially on behalf of the psychiatric/ mental health nursing leaderships.

\section{Declaration of interest}

The authors report no conflicts of interest and retain sole responsibility for the content and writing of this paper. 


\section{References}

1. Oulton J. A. The global nursing shortage: An overview of issues and actions. Policy, Politics \& Nursing Practice 2006; 7(3): 345-395.

2. Buchan J., O May F. \& Dussault G. Nursing workforce policy and the economic crisis: A global overview. Journal of Nursing Scholarship 2013; 45(3): 298-307. Doi: 10.1111/jnu. 12028

3. Chan Z. C. Y., Tam W. S., Lung M. K. Y., Wong W. Y. \& Chau C. W. A systematic literature review of nurse shortage and the intention to leave. Journal of Nursing Management 2013; 21: 605-613. Doi: 10.1111/j.1365-2834.2012.01437.x

4. Flinkman M. Young registered nurses' intent to leave the profession in Finland - A mixedmethod study. Doctoral Thesis: University of Turku; Annales Universitatis Turkuensis D 11072014.

5. Slater P. \& McCormack B. An exploration of the factor structure of the nursing work index. Worldviews on Evidence-Based Nursing 2007; 4(1): 30-39. Doi: 10.1111/j.17416787.2007.00076.x

6. Hyvönen J. The Finnish psychiatric health services in the 1990's from the point of view of historical continuity. Kuopio University Publications D. Medical Sciences 4402008

7. Hanrahan N. P. \& Aiken L. H. Psychiatric nurse reports on the quality of psychiatric care in general hospitals. Quality Management in Health Care 2008; 17(3): 210-217. Doi: 10.1097/01.QMH.0000326725.55460.af

8. Farmakas A., Papastavrou E., Siskou O., Karayiannas G. \& Theodorou M. Challenges in mental health nursing: working in institutional or community settings? Journal of Psychiatric and Mental Health Nursing 2014; 21: 39-45. Doi: 10.1111/jpm.12045

9. Johansson C., Åström S., Kauffeldt A., Helldin L. \& Carlström W. Culture as a predictor of resistance to change: A study of competing values in a psychiatric nursing context. Health Policy 2014; 114: 156-162. http://dx.doi.org/10.1016/j.healthpol.2013.07.014

10. Happell B. \& Koehn S. Seclusion as a necessary intervention: the relationship between burnout, job satisfaction and therapeutic optimism and justification for the use of seclusion. Journal of Advanced Nursing 2011; 67(6): 1222-1231. Doi: 10.1111/j.13652648.2010.05570.x

11. Happell B., Dares G., Russell A., Cokell S., Platania-Phung C. \& Gaskin C. J. The relationship between attitudes toward seclusion and levels of burnout, staff satisfaction, and therapeutic optimism in a district health service. Issues in Mental Health Nursing 2012; 33: 329-336. Doi: 10.3109/01612840.2011.644028

12. Paterson B., McIntosh I., Wilkinson D., McComish S. \& Smith I. Corrupted cultures in mental health inpatient settings. Is restraint reduction the answer? Journal of Psychiatric and Mental Health Nursing 2013; 20(3): 228-235. Doi: 10.1111/j.1365-2850.2012.01918.x

13. Manley K. Organisational culture and consultant nurse outcomes: Part 1 - Organisational culture. Nursing in Critical Care 2000; 5(4): 179-184. 
14. Scott-Findlay S. \& Estabrooks C.A. Mapping the organizational culture research in nursing: a literature review. Journal of Advanced Nursing 2006; 56 (5): 498-513. Doi:

10.1111/j.1365-2648.2006.04044.x.

15. Schein E. H. Organizational culture and leadership. $4^{\text {th }}$ edition. 2010, Jossey-Bass, San Francisco.

16. Sullivan E.J. \& Decker P.J. Effective Leadership and Management in Nursing. $7^{\text {th }}$ edition. 2009, Pearson International Edition, New Jersey.

17. Nardi D. A. \& Gyurko C. C. The global nursing faculty shortage: status and solutions for change. Journal of Nursing Scholarship 2013; 45(3): 317-326. Doi: 10.1111/jnu.12030

18. Goodnite P. M. Stress: A concept analysis. Nursing Forum 2013; 49(1): 71-74.

Doi:10.1111/nuf.12044

19. Sørgaard K. W., Ryan P., Hill R., Dawson I. \& the OSCAR group. Sources of stress and burnout in acute psychiatric care: inpatient vs. community staff. Social Psychiatry \& Psychiatric Epidemiology 2007; 42: 794-802. Doi: 10.1007/s00127-007-0228-6

20. Hamdan-Mansour A. M., Al-Gaal E., Puskar K., Yacoub M. \& Marini A. Mental health nursing in Jordan: An investigation into experience, work stress and organizational support. International Journal of Mental Health Nursing 2011; 20: 86-94. Doi: 10.1111/j.14470349.2010.00716.x.

21. Dallender J. \& Nolan P. Mental health work observed: a comparison of the perceptions of psychiatrists and mental health nurses. Journal of Psychiatric and Mental Health Nursing 2002; 9(2): 131-137. Doi: 10.1046/j.1365-2850.2002.00414.x

22. Slater P., McCormack B. \& Bunting B. The development and pilot testing of an instrument to measure nurses' working environment: The nursing context index. Worldviews on Evidence-Based Nursing 2009; 6(3): 173-182. Doi:10.1111/j.1741-6787.2009.00159.x

23. Ministry of Social Affairs and Health [Internet]. Helsinki: Act on Specialized Medical Care 1062/1989; 1989 [cited 2015 January 14]. Available from:

http://finlex.fi/en/laki/kaannokset/1989/en19891062?search[type]=pika\&search[pika]=speci alized

24. Ministry of Social Affairs and Health [Internet]. Helsinki: Mental Health Act 1116/1990; 1990 [Cited 2015 January 14]. Available from:

http://finlex.fi/en/laki/kaannokset/1990/en19901116?search[type]=pika\&search[pika]=ment al\%20health

25. Ministry of Social Affairs and Health [Internet]. Helsinki: Health Care Act 1326/2010; 2010 [Cited 2015 January 14]. Available from:

http://finlex.fi/en/laki/kaannokset/2010/en20101326?search[type]=pika\&search[pika]=healt h\%20care

26. Hahtela N., Paavilainen E., McCormack B., Slater P., Helminen M. \& Suominen T. Influence of workplace culture on nursing-sensitive nurse outcomes in municipal primary health care. Journal of Nursing Management 2014. Doi: 10.1111/jonm.12237. 
27. Eskola S., Roos M., McCormack B., Slater P., Hahtela N. \& Suominen T. (2016). Workplace culture among operating room nurses. Journal of Nursing Management 2016; Accepted.

28. Ministry of Social Affairs and Health [Internet]. Helsinki: Medical Research Act 488/1999; 1999 [Cited 2016 October 30]. Available from: http://www.finlex.fi/fi/laki/kaannokset/1999/en19990488.pdf

29. IBM Corp. IBM SPSS Statistics for Windows, Version 22.0. 2013, IBM Corp, Armonk, NY.

30. Jansen R. \& Venter I. Psychiatric nursing: an unpopular choice. Journal of Psychiatric and Mental Health Nursing 2015; 22(2): 142-148. Doi: 10.1111/jpm.12138

31. CPT European committee for the prevention of torture and inhuman or degrading treatment or punishment (CPT) [Internet]. Strasbourg: CPT standards ("Substantive" sections of the CPT's General Reports); 2015 [Cited 2016 April 9]. Available from: http://www.cpt.coe.int/en/documents/eng-standards.pdf 
Table 1. Demographic factors of respondents $(n=109)$

\begin{tabular}{|c|c|}
\hline Factors & $\%$ \\
\hline \multicolumn{2}{|l|}{ Age $(n=98)$} \\
\hline $22-33$ years & 34.7 \\
\hline $34-43$ years & 20.4 \\
\hline 44-69 years & 44.9 \\
\hline \multicolumn{2}{|l|}{ Gender $(n=109)$} \\
\hline Female & 62.4 \\
\hline Male & 37.6 \\
\hline \multicolumn{2}{|l|}{ Marital status (n=106) } \\
\hline Cohabitation/marriage & 73.6 \\
\hline Other & 26.4 \\
\hline \multicolumn{2}{|l|}{ Education (n=107) } \\
\hline Vocational school & 35.5 \\
\hline Polytechnic & 64.5 \\
\hline \multicolumn{2}{|l|}{ Job title $(n=107)$} \\
\hline Licenced or mental health nurse & 24.3 \\
\hline Registered nurse & 75.7 \\
\hline \multicolumn{2}{|l|}{ Basis of employment $(n=108)$} \\
\hline Permanent & 74.1 \\
\hline Temporary & 25.9 \\
\hline \multicolumn{2}{|l|}{ Working-time (n=109) } \\
\hline Full-time & 97.2 \\
\hline Part-time & 2.8 \\
\hline \multicolumn{2}{|l|}{ Working in shifts $(n=109)$} \\
\hline Three shift work & 75.2 \\
\hline Other & 24.8 \\
\hline \multicolumn{2}{|c|}{ Self-government with shifts $(n=108)$} \\
\hline No & 55.6 \\
\hline Yes & 44.4 \\
\hline \multicolumn{2}{|l|}{ Experience in nursing ( $n=107)$} \\
\hline$<1-9$ years & 34.6 \\
\hline $10-19$ years & 26.2 \\
\hline $20-40$ years & 39.2 \\
\hline \multicolumn{2}{|l|}{ Working in this hospital ( $\mathrm{n}=107)$} \\
\hline$<1-9$ years & 44.9 \\
\hline $10-14$ years & 17.8 \\
\hline $15-37$ years & 37.4 \\
\hline \multicolumn{2}{|l|}{ Working in this ward $(n=105)$} \\
\hline$<1-4$ years & 48.6 \\
\hline $5-9$ years & 16.2 \\
\hline 10-31 years & 35.2 \\
\hline \multicolumn{2}{|c|}{ Experience in outpatient care $(n=107)$} \\
\hline No & 74.8 \\
\hline Yes & 25.2 \\
\hline
\end{tabular}


Table 2. Deprivation of liberty

\begin{tabular}{lllll}
\hline & $\begin{array}{l}\text { Rarely(1) } \\
\mathrm{n}(\%)\end{array}$ & $\begin{array}{l}\text { Monthly(2) } \\
\mathrm{n}(\%)\end{array}$ & $\begin{array}{l}\text { Weekly(3) } \\
\mathrm{n}(\%)\end{array}$ & $\begin{array}{l}\text { Daily(4) } \\
\mathrm{n}(\%)\end{array}$ \\
\hline $\begin{array}{l}\text { Restrictions: } \\
\text { Confiscation of property (n=109) }\end{array}$ & $45(41.3)$ & $33(30.3)$ & $21(19.3)$ & $10(9.2)$ \\
Restrictions of communication $(\mathrm{n}=109)$ & $55(50.5)$ & $40(36.7)$ & $10(9.2)$ & $4(3.7)$ \\
Restrictions on leaving the ward (n=109) & $19(17.4)$ & $19(17.4)$ & $22(20.2)$ & $49(45.0)$ \\
Coercive measures: & & & & \\
Rooming-in (n=108) & $56(51.9)$ & $34(31.5)$ & $4(3.7)$ & $14(13.0)$ \\
Physical adherence $(\mathrm{n}=109)$ & $63(57.8)$ & $33(30.3)$ & $9(8.3)$ & $4(3.7)$ \\
Seclusion (n=108) & $52(48.1)$ & $37(34.3)$ & $17(15.7)$ & $2(1.9)$ \\
Restraint (n=108) & $80(74.1)$ & $16(14.8)$ & $6(5.6)$ & $6(5.6)$ \\
Forced medication $(\mathrm{n}=107)$ & $49(45.8)$ & $37(34.6)$ & $19(17.8)$ & $2(1.9)$ \\
\hline
\end{tabular}


Table 3. Constructs of workplace culture

\begin{tabular}{|c|c|c|c|c|c|}
\hline & Items & Mean (SD) & $\mathrm{Md}$ & $\mathrm{Q}_{1-} \mathrm{Q}_{3}$ & $\alpha$ \\
\hline Overall stress & 35 & $2.56(0.55)$ & 2.57 & $2.15-2.99$ & 0.90 \\
\hline 1. Workload & 5 & $3.49(1.00)$ & 3.40 & $2.65-4.20$ & 0.89 \\
\hline 2. Inadequate preparations & 3 & $3.21(0.86)$ & 3.00 & $2.67-3.67$ & 0.77 \\
\hline 3. Lack of communication and support & 5 & $2.85(0.91)$ & 2.70 & $2.20-3.40$ & 0.78 \\
\hline 4. Uncertainty regarding treatments & 4 & $2.77(0.90)$ & 2.75 & $2.00-3.50$ & 0.65 \\
\hline 5. Work-social life balance & 4 & $2.32(0.93)$ & 2.25 & $1.69-3.00$ & 0.77 \\
\hline 6. Lack of staff support & 3 & $2.20(0.77)$ & 2.00 & $1.67-2.67$ & 0.72 \\
\hline 7. Conflict with other nurses & 4 & $2.08(0.74)$ & 2.00 & $1.50-2.50$ & 0.64 \\
\hline 8. Career development & 4 & $2.08(0.81)$ & 2.00 & $1.25-2.50$ & 0.63 \\
\hline 9. Working environment & 3 & $1.98(0.90)$ & 2.00 & $1.33-2.33$ & 0.84 \\
\hline Overall satisfaction & 18 & $4.75(0.66)$ & 4.72 & $4.39-5.18$ & 0.87 \\
\hline 10. Personal satisfaction & 5 & $5.16(0.72)$ & 5.20 & $4.80-5.60$ & 0.81 \\
\hline 11. Professional satisfaction & 5 & $5.01(0.78)$ & 5.00 & $4.60-5.60$ & 0.68 \\
\hline 12. Satisfaction with training & 3 & $4.85(1.16)$ & 5.00 & $4.00-5.67$ & 0.90 \\
\hline 13. Satisfaction with pay and prospects & 5 & $3.98(0.91)$ & 4.00 & $3.40-4.70$ & 0.73 \\
\hline Overall practice environment & 24 & $4.42(0.81)$ & 4.38 & $4.00-5.00$ & 0.89 \\
\hline 14. Nurse management & 7 & $4.88(0.84)$ & 4.86 & $4.43-5.43$ & 0.76 \\
\hline 15. Intention to leave & 3 & $4.88(1.83)$ & 5.00 & $3.33-6.67$ & 0.94 \\
\hline 16. Doctor-nurse relationship & 3 & $4.77(1.38)$ & 5.00 & $3.67-6.00$ & 0.95 \\
\hline 17. Adequate staffing and resources & 4 & $4.04(1.25)$ & 4.25 & $3.00-5.00$ & 0.84 \\
\hline 18. Organizational commitment & 3 & $3.94(1.04)$ & 4.00 & $3.33-4.67$ & 0.82 \\
\hline 19. Empowerment & 4 & $3.57(1.15)$ & 3.50 & $2.81-4.25$ & 0.58 \\
\hline
\end{tabular}


Table 4.

Demographic variables associated with stress

\begin{tabular}{|c|c|c|c|c|c|c|c|c|c|c|c|c|c|}
\hline & & Age & & & & Marital status & & & Education & & & $\begin{array}{l}\text { Working in } \\
\text { shifts }\end{array}$ & \\
\hline & $22-33$ years & $34-43$ years & $44-69$ years & & $\begin{array}{l}\text { Cohabitation/ } \\
\text { marriage }\end{array}$ & Other & & $\begin{array}{l}\text { Vocational } \\
\text { school }\end{array}$ & Polytechnic & & $\begin{array}{l}\text { Three shift } \\
\text { work }\end{array}$ & Other & \\
\hline & Mean (SD) & Mean (SD) & Mean (SD) & $\mathrm{p}^{1}$ & Mean (SD) & Mean (SD) & $\mathrm{p}^{3}$ & Mean (SD) & Mean (SD) & $\mathrm{p}^{3}$ & Mean (SD) & Mean (SD) & $\mathrm{p}^{3}$ \\
\hline \multirow[t]{2}{*}{ Overall stress } & $2.5(0.57)$ & $2.6(0.38)$ & $2.5(0.59)$ & 0.702 & $2.5(0.64)$ & $2.6(0.51)$ & 0.467 & $2.4(0.60)$ & $2.6(0.51)$ & 0.192 & $2.6(0.56)$ & $2.5(0.54)$ & 0.383 \\
\hline & $\operatorname{Md}\left(\mathrm{Q}_{1}, \mathrm{Q}_{3}\right)$ & $\operatorname{Md}\left(\mathrm{Q}_{1}, \mathrm{Q}_{3}\right)$ & $\operatorname{Md}\left(\mathrm{Q}_{1}, \mathrm{Q}_{3}\right)$ & $\mathrm{p}^{2}$ & $\operatorname{Md}\left(\mathrm{Q}_{1}, \mathrm{Q}_{3}\right)$ & $\operatorname{Md}\left(Q_{1}, Q_{3}\right)$ & $\mathrm{p}^{4}$ & $\operatorname{Md}\left(Q_{1}, Q_{3}\right)$ & $\operatorname{Md}\left(Q_{1}, Q_{3}\right)$ & $\mathrm{p}^{4}$ & $\mathrm{Md}\left(\mathrm{Q}_{1}, \mathrm{Q}_{3}\right)$ & $\operatorname{Md}\left(Q_{1}, Q_{3}\right)$ & $\mathrm{p}^{4}$ \\
\hline Workload & $3.3(2.6,4.0)$ & $3.4(2.8,4.1)$ & $3.0(2.6,3.6)$ & 0.651 & $3.0(2.4,3.7)$ & $3.4(2.6,4.0)$ & 0.232 & $3.2(2.6,4.2)$ & $3.2(2.6,3.8)$ & 0.494 & $3.4(2.6,4.0)$ & $2.8(2.6,3.7)$ & 0.242 \\
\hline $\begin{array}{l}\text { Inadequate } \\
\text { preparations }\end{array}$ & $3.0(2.7,3,7)$ & $3.3(2.5,3.7)$ & $3.0(2.3,3.7)$ & 0.547 & $3.0(2.3,3.7)$ & $3.0(2.7,3.7)$ & 0.476 & $3.0(2.3,3.7)$ & $3.0(2.7,4.0)$ & 0.053 & $3.0(2.7,4.0)$ & $3.0(2.5,3.5)$ & 0.564 \\
\hline $\begin{array}{l}\text { Lack of } \\
\text { communication and } \\
\text { support }\end{array}$ & $2.8(2.4,3.5)$ & $2.6(2.2,3.3)$ & $2.4(2.0,3.0)$ & 0.525 & $2.4(2.0,3.3)$ & $2.6(2.2,3.2)$ & 0.347 & $2.4(2.0,3.4)$ & $2.6(2.2,3.2)$ & 0.183 & $2.6(2.0,3.2)$ & $2.4(2.0,3.2)$ & 0.161 \\
\hline $\begin{array}{l}\text { Uncertainty regarding } \\
\text { treatments }\end{array}$ & $2.5(2.0,3.0)$ & $2.5(2.1,3.4)$ & $2.6(2.0,3.3)$ & 0.527 & $2.3(1.9,2.6)$ & $2.8(2.0,3.5)$ & 0.144 & $2.5(2.0,3.3)$ & $2.5(2.0,3.3)$ & 0.538 & $2.5(2.0,3.5)$ & $2.8(2.0,3.3)$ & 0.729 \\
\hline $\begin{array}{l}\text { Work-social life } \\
\text { balance }\end{array}$ & $1.9(1.6,2.8)$ & $2.5(1.8,3.3)$ & $1.8(1.3,2.5)$ & 0.184 & $2.0(1.5,2.6)$ & $2.0(1.5,2.8)$ & 0.631 & $2.0(1.5,3.0)$ & $2.0(1.5,2.5)$ & 0.368 & $2.0(1.8,3.0)$ & $1.8(1.3,2.6)$ & $0.034^{*}$ \\
\hline Lack of staff support & $2.0(1.3,2.3)$ & $2.0(1.3,2.3)$ & $2.0(1.9,2.7)$ & 0.152 & $2.0(1.3,2.5)$ & $2.0(1.7,2.7)$ & 0.369 & $2.0(1.3,2.3)$ & $2.0(1.7,2.7)$ & 0.341 & $2.0(1.3,2.7)$ & $2.3(1.8,3.2)$ & 0.092 \\
\hline $\begin{array}{l}\text { Conflict with other } \\
\text { nurses }\end{array}$ & $1.8(1.1,2.2)$ & $2.0(1.5,2.8)$ & $2.0(1.5,2.5)$ & 0.178 & $1.5(1.0,2.0)$ & $2.0(1.6,2.5)$ & $0.005^{* *}$ & $1.8(1.3,2.3)$ & $2.0(1.5,2.5)$ & 0.303 & $2.0(1.5,2.5)$ & $1.8(1.5,2.3)$ & 0.214 \\
\hline Career development & $2.3(1.8,2.8)$ & $2.3(1.5,2.5)$ & $1.8(1.0,2.5)$ & $0.014^{*}$ & $2.3(1.8,2.5)$ & $2.0(1.3,2.5)$ & 0.805 & $2.0(1.3,2.3)$ & $2.3(1.5,2.5)$ & $0.012^{*}$ & $2.3(1.5,2.5)$ & $2.0(1.3,2.5)$ & 0.246 \\
\hline Working environment & $1.7(1.1,2.3)$ & $2.0(1.3,2.2)$ & $1.8(1.3,2.3)$ & 0.941 & $1.7(1.0,2.3)$ & $2.0(1.3,2.3)$ & 0.519 & $1.7(1.0,2.3)$ & $1.7(1.3,2.3)$ & 0.226 & $1.7(1.3,2.3)$ & $2.0(1.3,2.5)$ & 0.566 \\
\hline
\end{tabular}

${ }^{1}=$ one-way ANOVA, ${ }^{2}=$ Kruskal-Wallis -test, ${ }^{3}=\mathrm{t}$-test, ${ }^{4}=$ Mann-Whitney U -test, ${ }^{*} \mathrm{p}<.05, * * \mathrm{p}<.01, * * * \mathrm{p}<.001$ 
Table 4. Continued

\begin{tabular}{|c|c|c|c|c|c|c|c|c|c|c|}
\hline & & $\begin{array}{l}\text { Working } \\
\text { length in } \\
\text { present } \\
\text { hospital }\end{array}$ & & & & $\begin{array}{l}\text { Experience } \\
\text { in outpatient } \\
\text { care }\end{array}$ & & & $\begin{array}{l}\text { Restrictions } \\
\text { used }\end{array}$ & \\
\hline & $<1-9$ years & 10-14 years & 15-37 years & & No & Yes & & rare & often & \\
\hline & Mean (SD) & Mean (SD) & Mean (SD) & $\mathrm{p}^{1}$ & Mean (SD) & Mean (SD) & $\mathrm{p}^{3}$ & Mean (SD) & Mean (SD) & $\mathrm{p}^{3}$ \\
\hline \multirow[t]{2}{*}{ Overall stress } & $2.5(0.56)$ & $2.6(0.49)$ & $2.6(0.57)$ & 0.588 & $2.6(0.54)$ & $2.4(0.51)$ & 0.055 & $2.5(0.57)$ & $2.6(0.53)$ & 0.177 \\
\hline & $\mathrm{Md}\left(\mathrm{Q}_{1}, \mathrm{Q}_{3}\right)$ & $\mathrm{Md}\left(\mathrm{Q}_{1}, \mathrm{Q}_{3}\right)$ & $\mathrm{Md}\left(\mathrm{Q}_{1}, \mathrm{Q}_{3}\right)$ & $\mathrm{p}^{2}$ & $\mathrm{Md}\left(\mathrm{Q}_{1}, \mathrm{Q}_{3}\right)$ & $\operatorname{Md}\left(\mathrm{Q}_{1}, \mathrm{Q}_{3}\right)$ & $\mathrm{p}^{4}$ & $\operatorname{Md}\left(\mathrm{Q}_{1}, \mathrm{Q}_{3}\right)$ & $\mathrm{Md}\left(\mathrm{Q}_{1}, \mathrm{Q}_{3}\right)$ & $\mathrm{p}^{4}$ \\
\hline Workload & $3.2(2.6,3.8)$ & $3.2(2.6,4.0)$ & $3.4(2.6,4.2)$ & 0.493 & $3.4(3.0,4.2)$ & $2.6(2.4,3.5)$ & $0.002 * *$ & $3.2(2.6,3.9)$ & $3.2(2.6,4.0)$ & 0.741 \\
\hline $\begin{array}{l}\text { Inadequate } \\
\text { preparations }\end{array}$ & $3.0(2.3,3.3)$ & $3.3(2.7,4.0)$ & $3.3(2.7,3.7)$ & 0.179 & $3.0(2.7,3.7)$ & $3.0(2.6,3.4)$ & 0.153 & $3.0(2.3,3.7)$ & $3.0(2.7,3.7)$ & 0.668 \\
\hline $\begin{array}{l}\text { Lack of } \\
\text { communication and } \\
\text { support }\end{array}$ & $2.6(2.0,3.3)$ & $2.4(1.8,2.8)$ & $2.8(2.2,3.4)$ & 0.549 & $2.8(2.3,3.6)$ & $2.2(2.0,2.9)$ & $0.002 * *$ & $2.4(2.0,3.1)$ & $2.6(2.2,3.4)$ & 0.256 \\
\hline $\begin{array}{l}\text { Uncertainty regarding } \\
\text { treatments }\end{array}$ & $2.5(2.0,3.0)$ & $2.3(2.0,3.5)$ & $3.0(2.3,3.8)$ & 0.089 & $2.6(2.1,3.4)$ & $2.4(2.0,3.0)$ & 0.241 & $2.5(1.9,3.1)$ & $3.0(2.3,3.5)$ & $0.033^{*}$ \\
\hline $\begin{array}{l}\text { Work-social life } \\
\text { balance }\end{array}$ & $2.0(1.5,2.8)$ & $1.8(1.3,2.5)$ & $2.3(1.5,3.0)$ & 0.977 & $2.0(1.8,2.9)$ & $2.0(1.5,2.8)$ & 0.490 & $1.8(1.5,2.5)$ & $2.3(1.5,3.0)$ & 0.396 \\
\hline Lack of staff support & $2.0(1.3,2.7)$ & $2.0(1.7,2.3)$ & $2.3(2.0,2.7)$ & 0.368 & $2.0(1.3,2.3)$ & $2.2(2.0,3.1)$ & 0.194 & $2.0(1.3,2.5)$ & $2.0(1.7,2.7)$ & 0.125 \\
\hline $\begin{array}{l}\text { Conflict with other } \\
\text { nurses }\end{array}$ & $1.8(1.1,2.3)$ & $2.0(1.5,2.5)$ & $2.0(1.5,2.8)$ & $0.020^{*}$ & $2.0(1.5,2.5)$ & $1.9(1.5,2.3)$ & 0.110 & $1.8(1.3,2.3)$ & $2.0(1.8,2.5)$ & 0.146 \\
\hline Career development & $2.3(1.6,2.6)$ & $2.3(1.0,2.5)$ & $2.0(1.3,2.5)$ & 0.077 & $2.3(1.3,2.5)$ & $2.1(1.4,3.1)$ & 0.606 & $2.0(1.4,2.5)$ & $2.3(1.3,2.8)$ & 0.105 \\
\hline Working environment & $1.7(1.2,2.3)$ & $1.7(1.3,2.0)$ & $2.3(1.3,2.3)$ & 0.275 & $2.0(1.3,2.3)$ & $1.7(1.0,2.4)$ & 0.249 & $1.7(1.2,2.3)$ & $2.0(1.3,2.3)$ & 0.108 \\
\hline
\end{tabular}

${ }^{1}=$ one-way ANOVA, ${ }^{2}=$ Kruskal-Wallis -test, ${ }^{3}=$ t-test, ${ }^{4}=$ Mann-Whitney U -test, ${ }^{*} \mathrm{p}<.05, * * \mathrm{p}<.01, * * * \mathrm{p}<.001$ 
Table 5.

Demographic variables associated with satisfaction

\begin{tabular}{|c|c|c|c|c|c|c|c|c|c|c|c|c|c|c|}
\hline & & Education & & & $\begin{array}{l}\text { Basis of } \\
\text { employment }\end{array}$ & & & $\begin{array}{l}\text { Experience } \\
\text { in nursing }\end{array}$ & & & & $\begin{array}{l}\text { Working } \\
\text { length in } \\
\text { present } \\
\text { hospital }\end{array}$ & & \\
\hline & $\begin{array}{l}\text { Vocational } \\
\text { school }\end{array}$ & Polytechnic & & Permanent & Temporary & & $<1-9$ years & $10-19$ years & $20-40$ years & & $<1-9$ years & $10-14$ years & $15-37$ years & \\
\hline & Mean (SD) & Mean (SD) & $\mathrm{p}^{3}$ & Mean (SD) & Mean (SD) & $\mathrm{p}^{3}$ & Mean (SD) & Mean (SD) & Mean (SD) & $\mathrm{p}^{1}$ & Mean (SD) & Mean (SD) & Mean (SD) & $\mathrm{p}^{1}$ \\
\hline Overall satisfaction & $5.0(0.62)$ & $4.6(0.66)$ & $0.014^{*}$ & $4.8(0.65)$ & $4.6(0.65)$ & 0.139 & $4.6(0.70)$ & $4.6(0.56)$ & $5.0(0.66)$ & 0.060 & $4.6(0.70)^{\mathrm{a}}$ & $4.7(0.44)^{\mathrm{b}}$ & $5.0(0.65)^{\mathrm{c}}$ & $0.045^{*}$ \\
\hline \multirow{2}{*}{$\begin{array}{l}\text { Satisfaction with pay and } \\
\text { prospects }\end{array}$} & $4.2(0.84)$ & $3.9(0.91)$ & 0.099 & $4.0(0.92)$ & $3.8(0.87)$ & 0.249 & $3.9(0.87)$ & $3.9(0.86)$ & $4.1(0.98)$ & 0.518 & $3.9(0.92)$ & $3.9(0.88)$ & $4.2(0.91)$ & 0.214 \\
\hline & $\overline{M d}\left(\mathrm{Q}_{1}, \mathrm{Q}_{3}\right)$ & $\mathrm{Md}\left(\mathrm{Q}_{1}, \mathrm{Q}_{3}\right)$ & $\mathrm{p}^{4}$ & $\operatorname{Md}\left(\mathrm{Q}_{1}, \mathrm{Q}_{3}\right)$ & $\mathrm{Md}\left(\mathrm{Q}_{1}, \mathrm{Q}_{3}\right)$ & $\mathrm{p}^{4}$ & $\mathrm{Md}\left(\mathrm{Q}_{1}, \mathrm{Q}_{3}\right)$ & $\mathrm{Md}\left(\mathrm{Q}_{1}, \mathrm{Q}_{3}\right)$ & $\mathrm{Md}\left(\mathrm{Q}_{1}, \mathrm{Q}_{3}\right)$ & $\mathrm{p}^{2}$ & $\mathrm{Md}\left(\mathrm{Q}_{1}, \mathrm{Q}_{3}\right)$ & $\mathrm{Md}\left(\mathrm{Q}_{1}, \mathrm{Q}_{3}\right)$ & $\operatorname{Md}\left(\mathrm{Q}_{1}, \mathrm{Q}_{3}\right)$ & $\mathrm{p}^{2}$ \\
\hline Personal satisfaction & $5.0(4.8,5.8)$ & $5.2(4.8,5.6)$ & 0.911 & $5.0(4.8,5.6)$ & $5.4(5.0,5.7)$ & 0.822 & $5.4(4.9,5.8)$ & $5.0(4.4,5.4)$ & $5.3(4.8,5.8)$ & 0.366 & $5.4(4.6,5.7)$ & $5.0(4.6,5.6)$ & $5.2(5.0,5.8)$ & 0.468 \\
\hline Professional satisfaction & $5.2(4.8,6.0)$ & $5.0(4.6,5.6)$ & 0.105 & $5.0(4.6,5.6)$ & $5.2(4.5,5.6)$ & 0.948 & $5.2(4.5,5.6)$ & $5.0(4.4,5.6)$ & $5.2(4.8,5.7)$ & 0.600 & $5.2(4.6,5.6)$ & $5.0(4.6,5.2)$ & $5.2(4.6,5.6)$ & 0.520 \\
\hline Satisfaction with training & $5.0(5.0,6.0)$ & $4.7(3.3,5.3)$ & $0.009 * *$ & $5.0(4.7,6.0)$ & $4.0(3.0,5.5)$ & $0.001 * *$ & $4.7(3.2,5.3)$ & $5.0(4.0,5.0)$ & $5.3(5.0,6.0)$ & $0.002 * *$ & $5.0(3.3,5.3)$ & $4.7(4.0,5.7)$ & $5.3(5.0,6.0)$ & $0.005 * *$ \\
\hline
\end{tabular}

${ }^{1}=$ one-way ANOVA, ${ }^{2}=$ Kruskal-Wallis -test, ${ }^{3}=$ t-test, ${ }^{4}=$ Mann-Whitney U -test, ${ }^{*} \mathrm{p}<.05, * * \mathrm{p}<.01, * * * \mathrm{p}<.001$, $\mathrm{a}<\mathrm{c} \mathrm{p}=0.055$ 
Table 5. Continued

\begin{tabular}{|c|c|c|c|c|c|c|c|c|c|c|}
\hline & & $\begin{array}{l}\text { Working in } \\
\text { this ward }\end{array}$ & & & & $\begin{array}{l}\text { Restrictions } \\
\text { used }\end{array}$ & & & $\begin{array}{l}\text { Coercive } \\
\text { measures } \\
\text { used }\end{array}$ & \\
\hline & $<1-4$ years & $5-9$ years & $10-31$ years & & rare & often & & rare & often & \\
\hline & Mean (SD) & Mean (SD) & Mean (SD) & $\mathrm{p}^{1}$ & Mean (SD) & Mean (SD) & $\mathrm{p}^{3}$ & Mean (SD) & Mean (SD) & $\mathrm{p}^{3}$ \\
\hline Overall satisfaction & $4.6(0.69)^{d}$ & $4.4(0.50)^{\mathrm{e}}$ & $5.0(0.57)^{\mathrm{f}}$ & $0.004 * *$ & $4.9(0.56)$ & $4.6(0.72)$ & $0.005^{* * *}$ & $4.8(0.66)$ & $4.6(0.64)$ & 0.202 \\
\hline \multirow[t]{2}{*}{$\begin{array}{l}\text { Satisfaction with pay and } \\
\text { prospects }\end{array}$} & & & & & $4.2(0.78)$ & $3.8(0.99)$ & $0.017^{*}$ & $4.1(0.85)$ & $3.5(0.93)$ & $0.008 * *$ \\
\hline & $\mathrm{Md}\left(\mathrm{Q}_{1}, \mathrm{Q}_{3}\right)$ & $\operatorname{Md}\left(\mathrm{Q}_{1}, \mathrm{Q}_{3}\right)$ & $\mathrm{Md}\left(\mathrm{Q}_{1}, \mathrm{Q}_{3}\right)$ & $\mathrm{p}^{2}$ & $\mathrm{Md}\left(\mathrm{Q}_{1}, \mathrm{Q}_{3}\right)$ & $\mathrm{Md}\left(\mathrm{Q}_{1}, \mathrm{Q}_{3}\right)$ & $\mathrm{p}^{4}$ & $\mathrm{Md}\left(\mathrm{Q}_{1}, \mathrm{Q}_{3}\right)$ & $\mathrm{Md}\left(\mathrm{Q}_{1}, \mathrm{Q}_{3}\right)$ & $\mathrm{p}^{4}$ \\
\hline $\begin{array}{l}\text { Satisfaction with pay and } \\
\text { prospects }\end{array}$ & $3.8(3.2,4.8)$ & $3.8(3.5,3.9)$ & $4.2(3.8,4.8)$ & 0.099 & & & & & & \\
\hline Personal satisfaction & $5.2(4.6,5.6)$ & $5.0(4.6,5.5)$ & $5.4(4.9,5.8)$ & 0.360 & $5.4(4.9,5.8)$ & $5.2(4.6,5.6)$ & 0.105 & $5.2(4.8,5.6)$ & $5.2(4.6,6.0)$ & 0.955 \\
\hline Professional satisfaction & $5.1(4.6,5.6)$ & $4.7(4.6,5.1)$ & $5.2(4.9,5.6)$ & $0.029 *$ & $5.2(4.9,5.6)$ & $5.0(4.2,5.4)$ & $0.021 *$ & $5.2(4.8,5.6)$ & $5.0(4.4,5.6)$ & 0.338 \\
\hline Satisfaction with training & $4.8(3.3,5.3)$ & $5.0(3.5,5.1)$ & $5.3(4.8,6.0)$ & $0.012 *$ & $5.0(4.7,6.0)$ & $5.0(3.3,5.3)$ & 0.117 & $5.0(4.0,5.7)$ & $4.8(3.8,5.8)$ & 0.448 \\
\hline
\end{tabular}

${ }^{1}=$ one-way ANOVA, ${ }^{2}=$ Kruskal-Wallis -test, ${ }^{3}=\mathrm{t}$-test, ${ }^{4}=$ Mann-Whitney U -test, ${ }^{*} \mathrm{p}<.05, * * \mathrm{p}<.01, * * * \mathrm{p}<.001$

$\mathrm{d}<\mathrm{f} p=0.024, \mathrm{e}<\mathrm{f} \mathrm{p}=0.010$ 
Table 6.

Demographic variables associated with the practice environment

\begin{tabular}{|c|c|c|c|c|c|c|c|c|c|c|c|c|c|}
\hline & $22-33$ years & $34-43$ years & 44-69 years & & $\begin{array}{l}\text { Vocational } \\
\text { school }\end{array}$ & Polytechnic & & Permanent & $\begin{array}{l}\text { Basis of } \\
\text { employment } \\
\text { Temporary }\end{array}$ & & $\begin{array}{l}\text { Three shift } \\
\text { work }\end{array}$ & $\begin{array}{l}\text { Working in } \\
\text { shifts } \\
\text { Other }\end{array}$ & \\
\hline & Mean (SD) & Mean (SD) & Mean (SD) & $\mathrm{p}^{1}$ & Mean (SD) & Mean (SD) & $\mathrm{p}^{3}$ & Mean (SD) & Mean (SD) & $\mathrm{p}^{3}$ & Mean (SD) & Mean (SD) & $\mathrm{p}^{3}$ \\
\hline \multirow{2}{*}{$\begin{array}{l}\text { Organizational } \\
\text { commitment }\end{array}$} & $3.6(1.02)^{\mathrm{d}}$ & $3.8(1.00)^{\mathrm{e}}$ & $4.3(0.95)^{\mathrm{f}}$ & $0.017 *$ & $4.3(1.06)$ & $3.7(1.00)$ & $0.019^{*}$ & $4.0(0.99)$ & $3.7(1.10)$ & 0.143 & $3.8(0.94)$ & $4.5(1.14)$ & $0.001^{* *}$ \\
\hline & $\mathrm{Md}\left(\mathrm{Q}_{1}, \mathrm{Q}_{3}\right)$ & $\mathrm{Md}\left(\mathrm{Q}_{1}, \mathrm{Q}_{3}\right)$ & $\mathrm{Md}\left(\mathrm{Q}_{1}, \mathrm{Q}_{3}\right)$ & $\mathrm{p}^{2}$ & $\mathrm{Md}\left(\mathrm{Q}_{1}, \mathrm{Q}_{3}\right)$ & $\mathrm{Md}\left(\mathrm{Q}_{1}, \mathrm{Q}_{3}\right)$ & $\mathrm{p}^{4}$ & $\operatorname{Md}\left(Q_{1}, Q_{3}\right)$ & $\operatorname{Md}\left(\mathrm{Q}_{1}, \mathrm{Q}_{3}\right)$ & $\mathrm{p}^{4}$ & $\mathrm{Md}\left(\mathrm{Q}_{1}, \mathrm{Q}_{3}\right)$ & $\mathrm{Md}\left(\mathrm{Q}_{1}, \mathrm{Q}_{3}\right)$ & $\mathrm{p}^{4}$ \\
\hline Intention to leave & $5.3(3.0,6.9)$ & $4.0(2.7,6.2)$ & $6.0(4.5,7.0)$ & $0.038^{*}$ & $5.7(3.3,7.0)$ & $5.0(3.0,6.7)$ & 0.445 & $5.7(3.3,7.0)$ & $4.0(2.5,6.0)$ & $0.002 * *$ & $5.0(3.0,6.7)$ & $6.3(3.7,7.0)$ & 0.403 \\
\hline $\begin{array}{l}\text { Doctor-nurse } \\
\text { relationship }\end{array}$ & $5.0(4.1,6.0)$ & $4.3(3.0,5.8)$ & $5.7(5.0,6.0)$ & 0.166 & $5.0(3.7,6.0)$ & $5.0(4.0,6.0)$ & 0.955 & $5.0(3.7,6.0)$ & $5.0(4.2,6.0)$ & 0.794 & $5.0(3.7,6.0)$ & $5.7(4.8,6.0)$ & 0.153 \\
\hline $\begin{array}{l}\text { Adequate staffing and } \\
\text { resources }\end{array}$ & $4.8(2.8,5.5)$ & $4.0(2.6,4.9)$ & $4.4(3.5,5.0)$ & 0.637 & $4.3(3.5,5.0)$ & $4.5(3.0,5.3)$ & 0.941 & $4.3(3.0,5.0)$ & $4.8(3.0,5.3)$ & 0.393 & $4.3(3.0,5.0)$ & $4.5(3.6,5.3)$ & 0.392 \\
\hline Empowerment & $3.4(2.5,4.4)$ & $3.3(2.5,4.1)$ & $4.0(3.5,4.8)$ & $0.025^{*}$ & $4.0(3.5,4.8)$ & $3.5(2.8,4.5)$ & 0.053 & $3.5(2.5,4.3)$ & $3.8(2.9,4.5)$ & 0.801 & $3.5(2.5,4.3)$ & $4.5(3.8,5.1)$ & $<0.001 * * *$ \\
\hline
\end{tabular}

${ }^{1}=$ one-way ANOVA, ${ }^{2}=$ Kruskal-Wallis -test, ${ }^{3}=\mathrm{t}$-test, ${ }^{4}=$ Mann-Whitney U -test, $* \mathrm{p}<.05, * * \mathrm{p}<.01, * * * \mathrm{p}<.001$

$\mathrm{b}<\mathrm{c} p=0.060, \mathrm{~d}<\mathrm{f} p=0.019$ 
Table 6. Continued

\begin{tabular}{|c|c|c|c|c|c|c|c|c|c|c|c|}
\hline & No & $\begin{array}{l}\text { Self- } \\
\text { governance } \\
\text { with shifts } \\
\text { Yes }\end{array}$ & & $<1-9$ years & $\begin{array}{l}\text { Experience } \\
\text { in nursing }\end{array}$ & $20-40$ years & & $<1-9$ years & $\begin{array}{l}\text { Working } \\
\text { length in } \\
\text { present } \\
\text { hospital } \\
10-14 \text { years }\end{array}$ & 15-37 years & \\
\hline & Mean (SD) & Mean (SD) & $\mathrm{p}^{3}$ & Mean (SD) & Mean (SD) & Mean (SD) & $\mathrm{p}^{1}$ & Mean (SD) & Mean (SD) & Mean (SD) & $\mathrm{p}^{1}$ \\
\hline $\begin{array}{l}\text { Overall practice } \\
\text { environment }\end{array}$ & $4.5(0.84)$ & $4.3(0.77)$ & 0.403 & $4.2(0.94)^{g}$ & $4.3(0.70)^{\mathrm{h}}$ & $4.7(0.66)^{\mathrm{i}}$ & $0.021^{*}$ & & & & \\
\hline \multirow{2}{*}{$\begin{array}{l}\text { Organizational } \\
\text { commitment }\end{array}$} & $4.0(1.09)$ & $3.8(0.98)$ & 0.303 & $3.6(1.05)^{\mathrm{j}}$ & $3.8(1.03)^{\mathrm{k}}$ & $4.3(0.95)^{1}$ & $0.007^{* *}$ & $3.6(1.07)^{\mathrm{m}}$ & $3.7(0.75)^{\mathrm{n}}$ & $4.5(0.95)^{\circ}$ & $<0.001 * * *$ \\
\hline & $\operatorname{Md}\left(\mathrm{Q}_{1}, \mathrm{Q}_{3}\right)$ & $\operatorname{Md}\left(\mathrm{Q}_{1}, \mathrm{Q}_{3}\right)$ & $\mathrm{p}^{4}$ & $\operatorname{Md}\left(\mathrm{Q}_{1}, \mathrm{Q}_{3}\right)$ & $\operatorname{Md}\left(\mathrm{Q}_{1}, \mathrm{Q}_{3}\right)$ & $\operatorname{Md}\left(Q_{1}, Q_{3}\right)$ & $\mathrm{p}^{2}$ & $\operatorname{Md}\left(\mathrm{Q}_{1}, \mathrm{Q}_{3}\right)$ & $\operatorname{Md}\left(Q_{1}, Q_{3}\right)$ & $\operatorname{Md}\left(\mathrm{Q}_{1}, \mathrm{Q}_{3}\right)$ & $\mathrm{p}^{2}$ \\
\hline $\begin{array}{l}\text { Overall practice } \\
\text { environment }\end{array}$ & & & & & & & & $4.1(3.5,4.8)$ & $4.3(4.0,4.7)$ & $4.8(4.2,5.1)$ & $0.027 *$ \\
\hline Nurse management & $5.1(4.4,5.6)$ & $4.8(4.4,5.5)$ & 0.489 & $4.9(3.7,5.6)$ & $4.9(4.3,5.6)$ & $5.1(4.4,5.8)$ & 0.530 & $4.9(3.8,5.6)$ & $4.9(4.1,5.6)$ & $5.1(4.4,5.7)$ & 0.456 \\
\hline Intention to leave & $5.0(3.3,6.8)$ & $5.8(3.2,7.0)$ & 0.705 & $4.3(3.0,6.7)$ & $4.0(2.7,6.0)$ & $6.2(4.9,7.0)$ & $0.006^{* *}$ & $4.0(2.7,6.7)$ & $5.7(2.7,6.7)$ & $5.7(4.7,7.0)$ & $0.025^{*}$ \\
\hline $\begin{array}{l}\text { Doctor-nurse } \\
\text { relationship }\end{array}$ & $5.0(3.9,6.0)$ & $5.0(3.9,6.0)$ & 0.517 & $5.0(4.2,6.0)$ & $5.0(3.0,6.0)$ & $5.3(4.2,6.0)$ & 0.749 & $5.0(4.0,6.0)$ & $5.0(3.0,5.7)$ & $5.7(4.3,6.0)$ & 0.226 \\
\hline $\begin{array}{l}\text { Adequate staffing and } \\
\text { resources }\end{array}$ & $4.8(3.4,5.3)$ & $3.5(3.0,4.8)$ & $0.001 * *$ & $4.8(2.9,5.1)$ & $4.5(2.8,5.3)$ & $4.3(3.5,5.0)$ & 0.498 & $4.5(2.8,5.3)$ & $5.0(3.3,5.5)$ & $4.3(3.5,5.0)$ & 0.524 \\
\hline Empowerment & $3.5(2.5,4.3)$ & $4.0(3.2,4.5)$ & 0.255 & $3.5(2.5,4.5)$ & $3.3(2.5,4.3)$ & $4.0(3.5,4.8)$ & $0.033^{*}$ & $3.5(2.5,4.5)$ & $3.3(2.5,4.0)$ & $4.3(3.5,4.8)$ & $0.001 * *$ \\
\hline
\end{tabular}

${ }^{1}=$ one-way ANOVA, ${ }^{2}=$ Kruskal-Wallis -test, ${ }^{3}=\mathrm{t}$-test, ${ }^{4}=$ Mann-Whitney U -test, ${ }^{*} \mathrm{p}<.05, * * \mathrm{p}<.01, * * * \mathrm{p}<.001$

$\mathrm{g}<\mathrm{i} p=0.026, \mathrm{j}<1 \mathrm{p}=0.008, \mathrm{~m}<\mathrm{o} \mathrm{p}=0.001, \mathrm{n}<\mathrm{o} \mathrm{p}=0.014$ 
Table 6. Continued

\begin{tabular}{|c|c|c|c|c|c|c|c|c|c|c|}
\hline & $<1-4$ years & $\begin{array}{l}\text { Working in } \\
\text { this ward } \\
5-9 \text { years }\end{array}$ & $10-31$ years & & No & $\begin{array}{l}\text { Experience } \\
\text { in outpatient } \\
\text { care } \\
\text { Yes }\end{array}$ & & rare & $\begin{array}{l}\text { Restrictions } \\
\text { used } \\
\text { often }\end{array}$ & \\
\hline & Mean (SD) & Mean (SD) & Mean (SD) & $\mathrm{p}^{1}$ & Mean (SD) & Mean (SD) & $\mathrm{p}^{3}$ & Mean (SD) & Mean (SD) & $\mathrm{p}^{3}$ \\
\hline $\begin{array}{l}\text { Overall practice } \\
\text { environment }\end{array}$ & $4.4(0.86)$ & $4.1(0.80)$ & $4.7(0.65)$ & 0.085 & $4.4(0.80)$ & $4.5(0.82)$ & 0.547 & $4.5(0.79)$ & $4.4(0.83)$ & 0.424 \\
\hline \multirow{2}{*}{$\begin{array}{l}\text { Organizational } \\
\text { commitment }\end{array}$} & $3.7(1.08)^{\mathrm{q}}$ & $3.7(1.02)^{\mathrm{r}}$ & $4.4(0.90)^{\mathrm{s}}$ & $0.011 *$ & $3.9(1.05)$ & $4.0(1.08)$ & 0.945 & $4.0(1.06)$ & $3.9(1.02)$ & 0.494 \\
\hline & $\mathrm{Md}\left(\mathrm{Q}_{1}, \mathrm{Q}_{3}\right)$ & $\mathrm{Md}\left(\mathrm{Q}_{1}, \mathrm{Q}_{3}\right)$ & $\operatorname{Md}\left(\mathrm{Q}_{1}, \mathrm{Q}_{3}\right)$ & $\mathrm{p}^{2}$ & $\mathrm{Md}\left(\mathrm{Q}_{1}, \mathrm{Q}_{3}\right)$ & $\operatorname{Md}\left(\mathrm{Q}_{1}, \mathrm{Q}_{3}\right)$ & $\mathrm{p}^{4}$ & $\operatorname{Md}\left(\mathrm{Q}_{1}, \mathrm{Q}_{3}\right)$ & $\mathrm{Md}\left(\mathrm{Q}_{1}, \mathrm{Q}_{3}\right)$ & $\mathrm{p}^{4}$ \\
\hline Nurse management & $4.9(4.4,5.6)$ & $4.3(3.0,5.1)$ & $5.0(4.4,5.6)$ & 0.237 & $4.9(4.4,5.6)$ & $5.0(4.4,5.7)$ & 0.754 & $4.9(4.4,5.6)$ & $4.9(4.3,5.6)$ & 0.221 \\
\hline Intention to leave & $5.5(3.0,6.8)$ & $3.2(2.6,6.0)$ & $5.7(4.5,7.0)$ & 0.632 & $5.2(3.0,6.9)$ & $4.5(3.3,7.0)$ & 0.695 & $6.0(3.3,7.0)$ & $4.3(2.7,6.7)$ & $0.016^{*}$ \\
\hline $\begin{array}{l}\text { Doctor-nurse } \\
\text { relationship }\end{array}$ & $5.5(4.6,6.0)$ & $5.5(4.0,6.1)$ & $5.0(3.0,6.0)$ & 0.101 & $5.0(3.4,6.0)$ & $5.3(4.6,6.0)$ & $0.033^{*}$ & $5.0(3.7,6.0)$ & $5.0(4.0,6.0)$ & 0.427 \\
\hline $\begin{array}{l}\text { Adequate staffing and } \\
\text { resources }\end{array}$ & $4.8(3.0,5.1)$ & $3.4(2.4,4.4)$ & $4.3(3.4,5.1)$ & 0.493 & $4.3(3.0,5.0)$ & $4.9(3.0,5.6)$ & 0.082 & $4.3(3.0,4.9)$ & $4.8(3.0,5.5)$ & 0.217 \\
\hline Empowerment & $3.4(2.0,4.5)$ & $3.3(2.5,3.8)$ & $4.0(3.5,4.6)$ & 0.082 & $3.5(2.6,4.4)$ & $4.0(2.9,4.5)$ & 0.407 & $3.5(2.5,4.5)$ & $4.0(3.0,4.5)$ & 0.555 \\
\hline
\end{tabular}

${ }^{1}=$ one-way ANOVA, ${ }^{2}=$ Kruskal-Wallis -test, ${ }^{3}=\mathrm{t}$-test, ${ }^{4}=$ Mann-Whitney U -test, ${ }^{*} \mathrm{p}<.05, * * \mathrm{p}<.01, * * * \mathrm{p}<.001$ $\mathrm{q}<\mathrm{s} \mathrm{p}=0.019$ 